\title{
IMPORTANT ANNOUNCEMENT
}

\section{Journal of British Studies}

Journal of British Studies and Cambridge University Press are delighted to announce a new publishing partnership

\section{Editors}

Brian Cowan, Mc Gill University, Canada

Elizabeth Elbourne, McGill University, Canada

From 2013, Journal of British Studies will be published by Cambridge University Press on behalf of the North American Conference on British Studies (NACBS). Subscriptions, including 2013 renewals, and customer service issues will be managed by Cambridge.

Journal of British Studies's transition to Cambridge brings a wealth of benefits to subscribers, including:

- All institutional subscriptions to Journal of British Studies will include online access to current articles via Cambridge Journals Online (CJO)

- Availability of complete online archive: Volumes 1 through 50, plus the complete archive of Albion, a complementary journal formerly published by the NACBS

- Dedicated customer service and sales teams will help you manage the transition of your subscription

- Clear and familiar lines of communication are available for claims and subscription renewal

If you are a current subscriber, you will receive your regular renewal notice. You may return this notice directly to Cambridge or continue to order through your subscription agent. Please note that the journal will no longer be available as part of the JSTOR Current Scholarship Program. If you would like to subscribe, the contact details for our Customer Services Departments are listed in the column to the right.

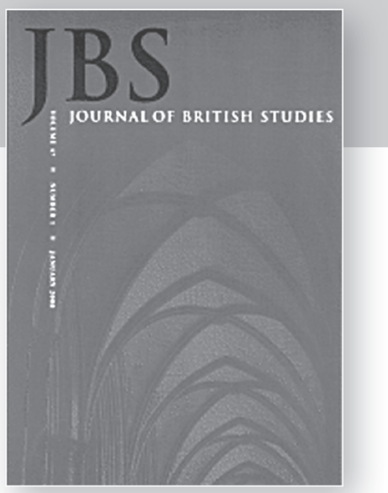

Journal of British Studies

http://journals.cambridge.org/jbr

To subscribe contact

Customer Services

\section{in Cambridge:}

Phone +44 (0)1223 326070

Fax +44 (0)1223 325150

Email journals@cambridge.org

in New York:

Phone (845) 3537500

Fax (845) 3534141

Email

subscriptions_newyork@cambridge.org

\section{Free email alerts}

Register today for free ETOC alerts and sample content as soon as it is available

journals.cambridge.org/jbr-alerts 


\section{CAMBRIDGE}

\section{JOURNALS}
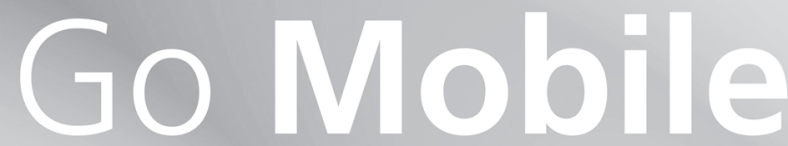

CJO Mobile (CJOm) is a streamlined

Cambridge Journals Online (CJO)

for smartphones and other small mobile devices

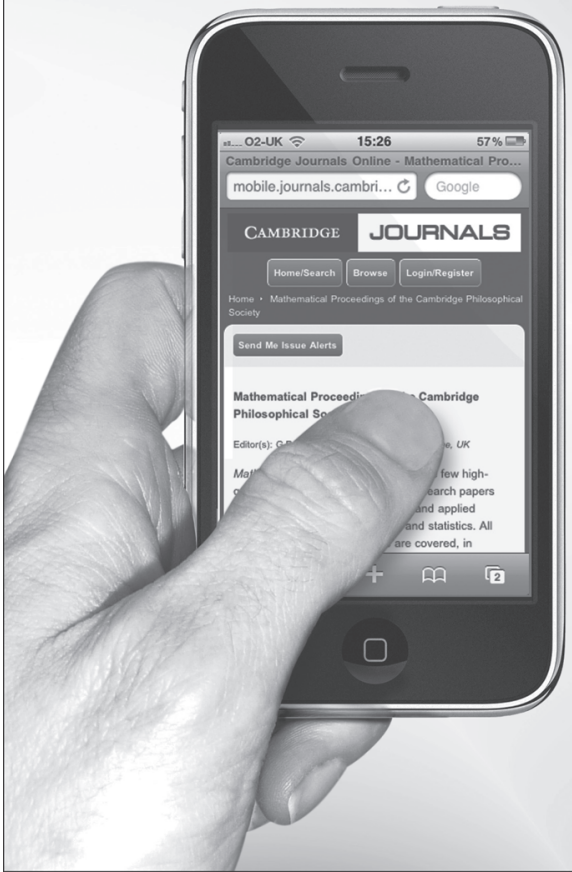

- Use CJOm to access all journal content including FirstView articles which are published online ahead of print

- Access quickly and easily thanks to simplified design and low resolution images

- Register for content alerts or save searches and articles they will be available on both CJO and CJOm

- Your device will be detected and automatically directed to CJOm via: journals.cambridge.org

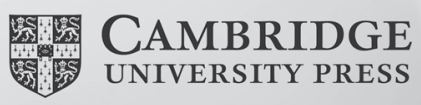




\section{JOURNALS}

\section{Knowledge is no longer shelved}

The Cambridge Journals Digital Archive

contains more than 160 journals, more than

3 million pages and more than 8 million

linked references. Knowledge is now more visible and more searchable than ever.
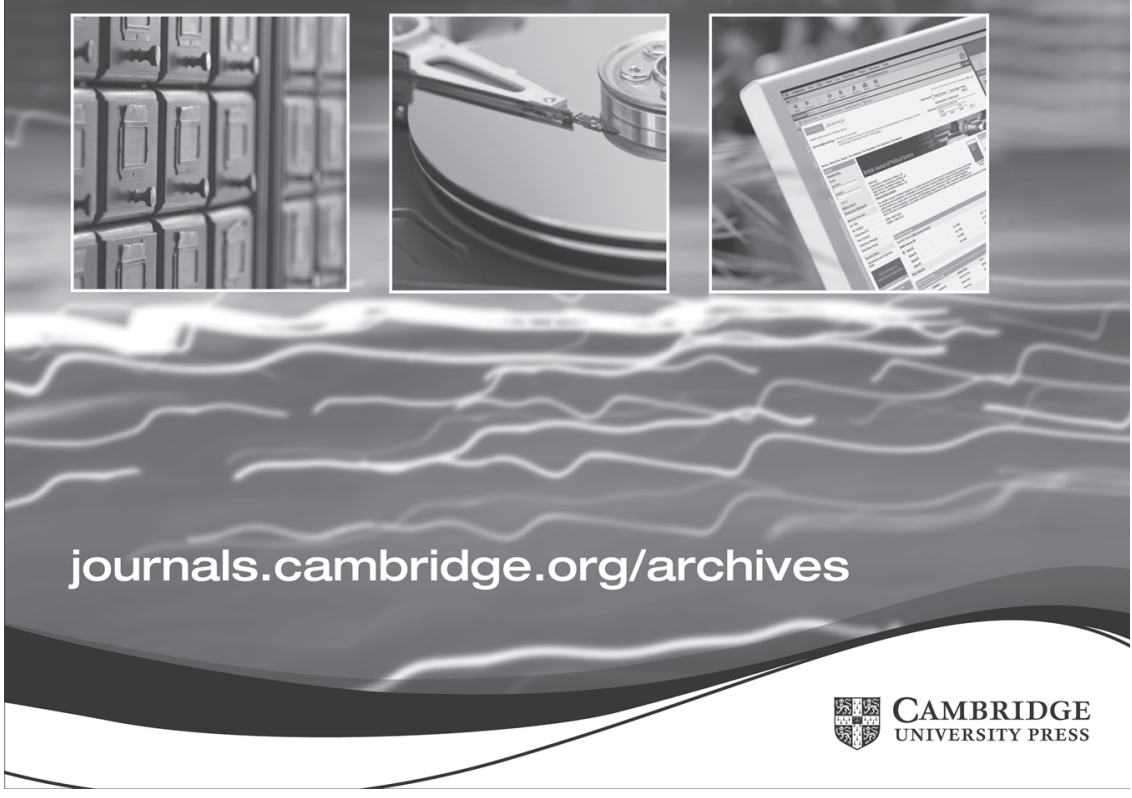


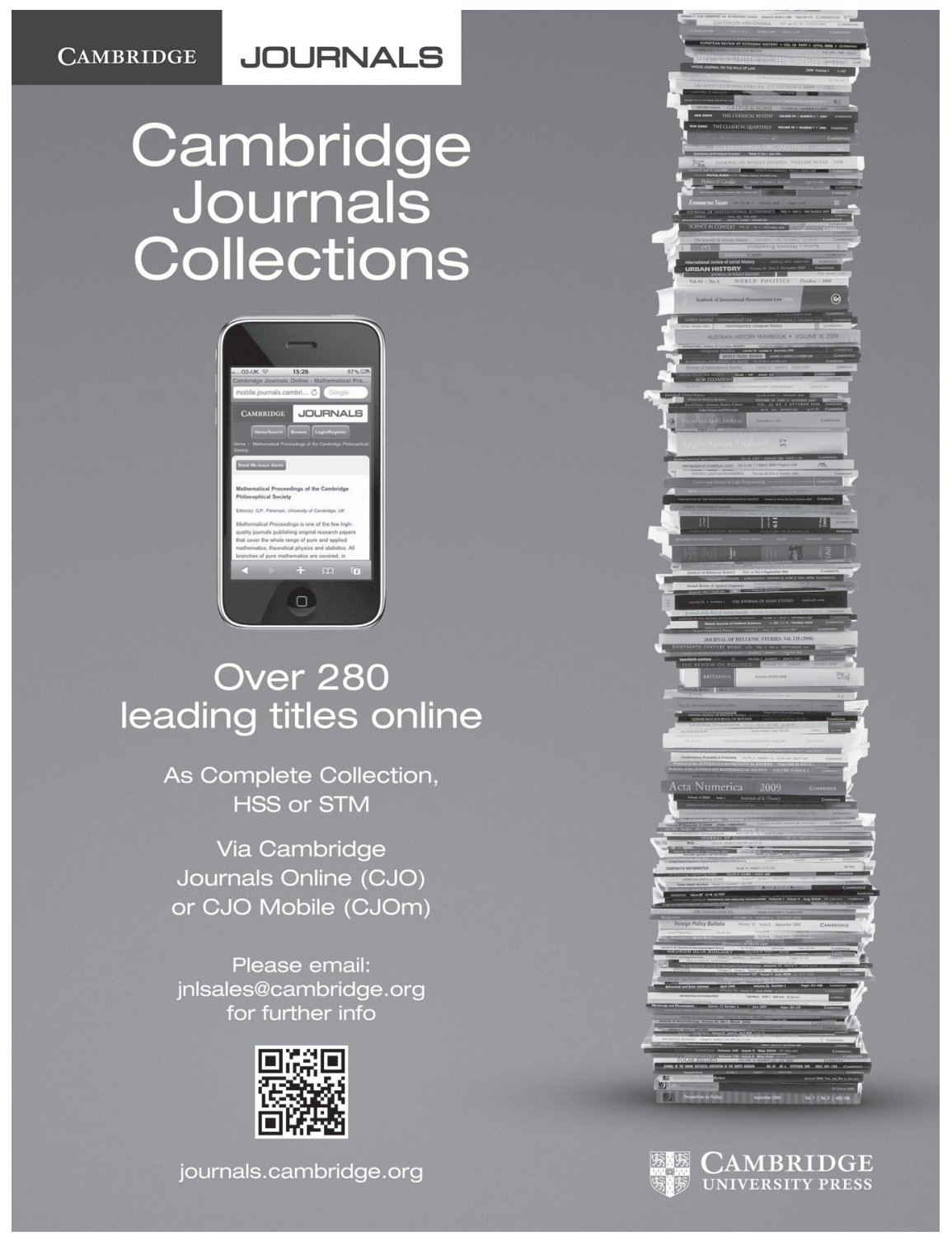




\section{CAMBRIDGE JDURNALS}

\section{Journal of the Society for American Music}

Published for The Society for American Music

\section{Editor}

Leta Miller, University of California, Santa Cruz, USA

The Journal of the Society for American Music is an international, peer-reviewed journal dealing with all aspects of American music and music in the Americas. JSAM is dedicated to supporting scholarship that transcends disciplinary boundaries, cutting across historical musicology, music theory, ethnomusicology, cultural theory, identity studies, and American studies. JSAM encourages international dialogue across disciplines. The journal features articles; reviews of books, recordings, and multimedia items; and explorations of special topics.

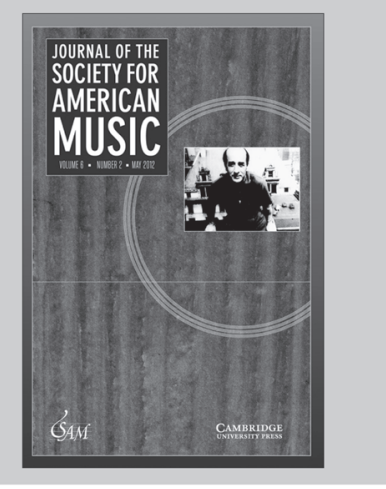

Journal of the Society for American Music

is available online at:

http://journals.cambridge.org/sam

To subscribe contact Customer Services

\section{in Cambridge:}

Phone +44 (0)1223 326070

$\mathrm{Fax}+44(0) 1223325150$

Email journals@cambridge.org

\section{in New York:}

Phone +1 (845) 3537500

Fax +1 (845) 3534141

Email

subscriptions_newyork@cambridge.org

\section{Free email alerts}

Keep up-to-date with new material - sign up at

journals.cambridge.org/register 


\section{Editorial policy}

Journal of American Studies publishes works by scholars from all over the world on American literature, history, institutions, politics, economics, film, popular culture, geography and related subjects.

A 'Notes and Comments' section provides a forum for shorter pieces and responses from readers to points made in articles or reviews.

\section{Submissions}

Papers should be submitted via the following website

http://mc.manuscriptcentral.com/jamstuds. Authors who do not yet have an account on the online submission site will need to register before submitting a manuscript. If you are unsure about your login details or whether you have an account or not, please use the password help field on the login page. Do not create a new account if you are unsure.

If you experience any difficulties submiting your manuscript, please contact ScholarOne support at

http://mchelp.manuscriptcentral.com/gethelpnow/question.htm

Any editorial correspondence should be addressed to: Professor Scott Lucas, W.S.Lucas@bham.ac.uk.

Submission of an article is taken to imply that it has not previously been published, and has not been submitted for publication elsewhere. Authors of articles published in the journal assign copyright to Cambridge University Press (with certain rights reserved) and will receive a copyright assignment form for signature on acceptance of your paper.

Contributors are responsible for obtaining permission to reproduce any material in which they do not own copyright, to be used in both print and electronic media, and for ensuring that the appropriate acknowledgements are included in their manuscript.

\section{Manuscript preparation}

Articles should not exceed 7,000 words.

Manuscripts should be submitted via the online submission system at http://mc.manuscriptcentral.com/jamstuds. Authors should remove their name from the manuscript and should ensure that their manuscript is fully anonymised.

File names should be of the type AMSauthor surname.doc or .rtf for ease of identification.

Diagrams, maps, and illustrations should be made into an eps file or a tif file and the file name should be AMSauthorsurname1.eps or .tif (where the number is the figure number).

Contributors should keep one copy of the typescript for correcting proofs.

\section{Text preparation}

Spelling and punctuation may conform either to British or American usage, providing it is consistent throughout. In either case quotation should follow the style of the original.

Use -ize (as in organize), connection, enquiry, judgement, focussed, role; elite, regime (without accents), but communiqué.

Quotations: Long quotations (i.e., of 50 words or more) will be set apart in smaller type, without quotation marks. They should also be indicated on the typescript. Shorter quotations will be set in the text, with double quotations within quotations, use single inside double.

Punctuation: All commas and periods ending quotations should appear inside the quotation marks; other punctuation goes outside unless it is actually part of the matter quoted.

Ellipsis within a sentence should be indicated by three ... spaced periods. Ellipsis at the end of a sentence should be indicated by three spaced periods following the sentence period, i.e. four periods in all.

Indentation: The first line of articles and of sections within articles and of reviews should not be indented. All other paragraphs begin with indentation.

Dates: 13 January 1976 (but 13 Jan. in footnotes); March 1978; 1920s; 1965-68; 1904-08 (except in headings: 1771-1773); seventeenth century; always abbreviate months in footnotes.
Figures: Spell one to ninety-nine in text, except e.g. 75 voted for, 39 against, and 15 abstained. Spell only one to nine in footnotes. 15 percent (but use \% in footnotes).

Abbreviations: Mr., Dr., Jr., Sr. (as in Richard Henry Dana, Sr.); but USA, USSR, UN, NATO, ACLS, DAB, PMLA (without periods). Ibid., et al., etc., loc. cit. (Latin with periods).

Tables: Use space rather than vertical rules, unless the latter are absolutely essential sources and notes should appear immediately below each table.

Footnotes should be used sparingly: in general, to give sources of direct quotations, references to main authorities on disputable questions, and evidence relied on for a new or unusual conclusion. They should be numbered consecutively.

Capitalization: southern, northern, southerner, northerner, governor, President of the United States, South, North, Midwest.

Citations should wherever possible be to authoritative editions rather than to paperback reprints of no textual authority.

Books should be cited as follows, complete with publisher's name:

W.R. Brock, American Crisis: Congress and Reconstruction 1865-1867 (London: Macmillan, 1963), 274-83

H.C. Allen and C.P. Hill, eds., British Essays in American History (London: Edward Arnold, 1957)

Frances Anne Kemble, Journal of a Residence on a Georgia Plantation in 1838-1939, ed. John A. Scott (New York: Alfred A. Knopf, 1961), $260 f f$.

John Livingstone Lowes, The Road to Xanadu: A Study in the Ways of the Imagination 2nd edn. (1930; rept. New York: Alfred A. Knopf, 1959), 61.

Helen T. Catterall, ed., Judicial Cases Concerning American Slavery and the Negro, 5 vols. (Washington, DC: US Govt. Printing Office, 1926-37), 1, 216-21, 247; 4, 16.19 .

John M. Hill, An Introduction to American Fiction, 2nd edn. rev. (Princeton: Princeton University Press, 1976), xi-xiii.

Subsequent citations should be indicated thus:

Immediately following: Ibid., 47.

Within the next ten footnotes: Hill, 271-78

When the work has not been cited, in any form, for more than ten footnotes: Hill, American Fiction, 394

Avoid op. cit.

Journals should be cited as follows:

Bernard Poli, "The Hero in France and America," Journal of American Studies, 2 (1968), 225-38

Avoid Roman numerals. Indicate volume numbers by italicising, thus: 64

Vol. No. Ch. Pt. all cap.

Page numbers: 152-55, 113-257, 1365-69

Abbreviations to be italic, e.g. Reviews in North America Literature, hereafter abbreviated to RNAL.

Weekly magazines

"Who controls the Democratic Party?" Time, 19 Sept. 1975, 19-24

Newspapers

Norman Mailer, "Reflections on James Baldwin's 'Apocalypse", New York Times, 9 Oct. 1968, 23.

\section{Proofs}

Typographical or factual errors only may be changed at proof stage. The publisher reserves the right to charge authors for correction of nontypographical errors.

\section{Offprints}

Article authors will receive a PDF file of their work.

This journal issue has been printed on FSC-certified paper and cover board. FSC is an independent, non-governmental, not-for-profit organization established to promote the responsible management of the world's forests. Please see www.fsc.org for information. 


\section{American}

Volume 46 Number 4 November 2012

$\checkmark$ Editors' Introduction

\section{ARTICLES}

803 Elizabeth Bishop in Brazil and the New Yorker FIONA GREEN

831 Staging Diaspora: South Asian American TheaterToday ASHIS SENGUPTA

855 Imagining Boston: Haitian Immigrants and Place in Zadie Smith's On Beauty REGINE JACKSON

875 Who Speaks for Harlem? Kenneth B. Clark, Albert Murray and the Controversies of Black Urban Life

DANIEL MATLIN

895 ¿SoyEmo, Y Qué? Sad Kids, Punkera Dykes and the Latin@ Public Sphere MARISSA LÓPEZ

919 Desire among the Ruins: The Politics of Difference in American Visions of Porfirian Mexico

JASON RUIZ

941 "The Voice in the Picture": Reversing the Angle in Vietnamese American War Memoirs

HELENA GRICE

959 Suburban Gothic and the Ethnic Uncanny in Jeffrey Eugenides's The Virgin Suicides

MARTIN DINES

977 Lorine Niedecker, Henri Bergson and the Poetics of Temporal Flow VICTORIA BAZIN

997 "What the Hell Is a Flowery Boundary Tree?" Guns/inger, A/l the Pretty Horses and the Postmodern Western JORDAN SAVAGE

1009 Arguing Slavery's Narrative: Southern Regionalists, Ex-slave Autobiographers, and the Contested Literary Representations of the Peculiar Institution, 1824-1849 CALVIN SCHERMERHORN

1035 Jayhawker Fraternities: Masons, Klansmen and Kansas in the 1920s KRISTOFER ALLERFELDT

1055 Reading the Market: Abstraction, Personification and the Financial Column of Town Topics Magazine

PETER KNIGHT

1077 ROUND TABLE

1095 REVIEWS

ROUND TABLE

EXCLUSIVE ONLINE REVIEWS www.journals.cambridge.org/ams

Cambridge Journals Online

For further information about this journal

please go to the journal website at:

journals.cambridge.org/ams

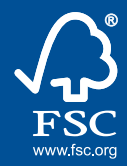

MIX
$\begin{gathered}\text { Paper from } \\ \text { responsible sources }\end{gathered}$
FSC $^{\circledast}$ C018575
CAMBRIDGE UNIVERSITY PRESS 